\title{
CHARLES H. LANKESTER (1879-1969): HIS LIFE AND LEGACY
}

\author{
Carlos Ossenbach
}

Orquideario 25 de mayo

\begin{abstract}
Charles Herbert Lankester (1879-1969) was without a doubt the most dominant figure of Central American orchidology during his time. Better known as 'Don Carlos', Lankester was born in Southampton, England, on June 14 1879. It was in London that he read an announcement offering a position to work as an assistant to the recently founded Sarapiquí Coffee Estates Company in Costa Rica, he applied and was hired. Surely influenced by his uncle's zoological background, Lankester was at first interested in birds and butterflies. However, living in Cachí, at that time one of the regions with the greatest botanical diversity, he must have fallen under the spell of the plant world as he soon began collecting orchids in the nearby woods. Many of the plants he collected at this time proved to be new species. With no literature at his hand to determine the plants he collected, Lankester started corresponding with the assistant director of the Royal Botanic Gardens at Kew, Arthur Hill in 1910, and somewhat later with Robert Allen Rolfe, Kew's most eminent authority on orchids. At the same time, Lankester began his collection of living plants that would become so famous years later. He returned to England in 1920 to enroll his five children in English schools. Lankester traveled to Africa from 1920 to 1922, hired by the British Government to do research on coffee plantations in Uganda. When returning to England, he found that Rolfe had died the year before. Many orchids that he had brought to Kew were left without identification. Lankester was back in Costa Rica in 1922, the year that was a turning point in his career as an orchidologist: it brought the first correspondence with Oakes Ames. Over the next fifteen years, Ames would discover more than 100 new species among the specimens he received from Costa Rica. In 1922, Ames began a series of publications on orchids, which he named Schedulae Orchidianae. In its third fascicle, in January 1923, Ames started to describe many of the Lankester orchids, which were deposited at Kew and had been left unidentified. Ames kept asking Lankester to send more and more specimens. After 1930, Lankester and Ames seem to drift slowly apart. Ames was taken in more by administrative work at Harvard, and Lankester traveled abroad more frequently. In 1955, after his wife's death and already 76 years old, Lankester decided to sell his farm but retained the small part which contained his garden, a piece of land called "El Silvestre". Lankester moved to a house he had bought in Moravia, one of the suburbs of the capital, San José. On a section of this farm called "El Silvestre", Lankester began his wonderful collections of orchids and plants of other families, which formed the basis of the Charles H. Lankester Botanical Garden of the University of Costa Rica.
\end{abstract}

Key words: Charles H. Lankester, Costa Rica, botany, history

"Twenty three years ago today, the good ship 'Atrato' (now alas asleep in the depths off the $N$. Irish coast) left Southampton with myself on board en route for Costa Rica, and here I am still ..."

Charles Lankester, letter to Oakes Ames, December 1923

Three famous names form the most illustrious trio of collectors in Costa Rica's history of orchidology: Auguste R. Endrés (1838-1874), Alberto Manuel
Brenes (1870-1948) and Charles Herbert Lankester (1879-1969). Undoubtedly the most important of the three was Auguste R. Endrés, who prepared the country's first monographical treatment of a plant family. His orchid collections, with over 3,500 numbers, form an important part of the Reichenbach orchid herbarium at the Vienna Natural History Museum. In the first decades of the twentieth century, Alberto Manuel Brenes, born in San Ramón when Endrés was living in this small city of the northwestern

\footnotetext{
* This paper was prepared in the framework of the celebration of Lankester Botanical Garden's $40^{\text {th }}$ anniversary.
} 


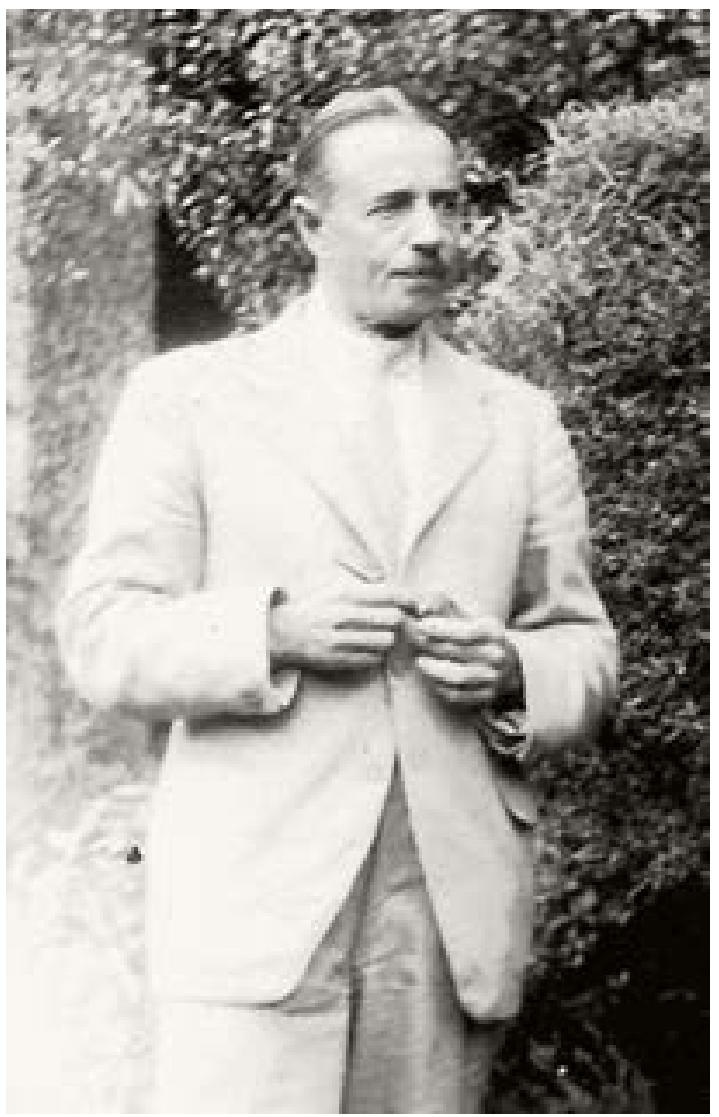

FiguRE 1. Charles H. Lankester (1879-1969), photographed ca. 1925.

Central Valley, did little botanical work but made extraordinary collections of orchids in the surrounding mountains. These include dozens of new species, described by Rudolf Schlechter in his Additamenta ad Orchideologiam Costaricensem (1923) in a chapter entitled Orchidaceae Brenesianae.

But it would be Charles Herbert Lankester (1879-1969) (Fig. 1), without doubt the dominant figure of Central American orchidology during his time, who should rightly bear the soubriquet of lynxeyed investigator, given by Reichenbach some 50 years earlier to Auguste R. Endrés.

The early years (1900-1908). Better known as 'Don Carlos', Lankester was born in Southampton, England, on June 14 1879, the son of Charles Lankester and Helen West. He lost both parents when only three years old and was raised, together with his sister, by two aunts. After finishing school he started work at a photographic

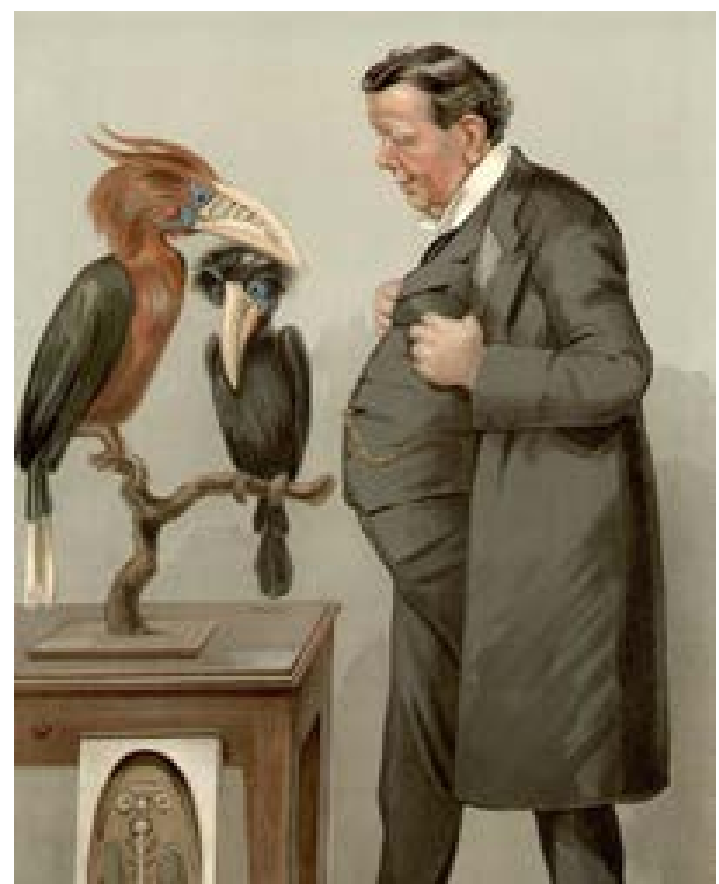

FIgURE 2. Ray Lankester by Leslie Ward, Vanity Fair, 1905.

studio and later went to London, where he specialized in color photography at the Polytechnic Institute. It was in London that he read an announcement in the Daily Telegraph, offering a position in Costa Rica to a young Englishman willing to work as an assistant to the recently founded Sarapiquí Coffee Estates Company. Lankester applied and was hired, landing a few months later in Puerto Limón, then going on by train to the capital of Costa Rica, where he arrived just in time to take part in the "Ball of the New Century", given by the president of Costa Rica, Rafael Yglesias, in the National Theater, San José.

Sarapiquí, in the Atlantic region, proved too humid for the commercial production of coffee and the plantations had to be abandoned three years after Don Carlos' arrival. It was here, surrounded by the most exuberant tropical vegetation, that his interests in plants, insects and birds began. As Dr. Louis Williams wrote in his obituary, "Don Carlos Lankester arrived at the right place at the right time to join into the active biological exploration of Costa Rica, perhaps the most exciting place biologically on our continent."

Lankester was not the first talented natural historian in his family; his father's cousin, Sir Edwin Ray Lankester (1847-1929) (Fig. 2), had been the third 
Director of the Natural History Museum in London.

The arrival of Lankester in Costa Rica marked the end of a period - the last two decades of the nineteenth century - which had shown for the first time the development of a 'national science' in Central America. In Costa Rica, as part of an educational reform aimed at secularizing public education, the government of president Bernardo Soto (1885-1889) hired a group of European academics to staff the two new public high schools in the capital, San José;The 'Liceo de Costa Rica' for boys and the 'Colegio Superior de Señoritas' for girls, both founded under Soto's administration. The arrival of these academics marks the beginning of a small scientific awakening in Costa Rica. Two institutions symbolize this: the Instituto Físico-Geográfico (IFG) (='Physical-Geographical Institute') and the National Museum, founded in 1889 and 1887, respectively.

Among the teachers hired were Pablo Biolley (1861-1908) and Henri Francois Pittier (1857-1950) (Fig. 3), who arrived in 1886 and 1887. Pittier lived in Costa Rica until 1905 and spent some of this time conducting a systematic exploration of the Costa Rican flora; a study that had no equal in any country of tropical America at that time. According to Paul C. Standley, in his introduction to the Flora of Costa Rica: "Henri Pittier [...] undoubtedly gained a more intimate knowledge of the natural history and especially the botany of Central America and northwestern South America than has ever been possessed by any single person (Standley, 1937:49)."

The combined labors of Pittier and Biolley, and, somewhat later, of Anastasio Alfaro, Adolph Tonduz, Carl Wercklé, and Brenes as well as the Brade brothers (Alfredo and Alexander Curt) resulted in the formation of the National Herbarium, which initially comprised more than 5,000 species. Again citing Standley, in 1903 the National Herbarium "was unequaled below the Río Grande del Norte (Standley, 1937:50).”

Lankester and Pittier began a lifelong friendship when the latter visited Sarapiquí. The other players in this scientific awakening, Alfaro, Biolley, Tonduz, Wercklé, the Brades, and, years later, Otón Jiménez would also be important to Lankester, as they often accompanied him on his collecting excursions and were frequent visitors to his farm in Cartago.

When his contract expired, Lankester went back to England. He returned to Costa Rica a few months later,

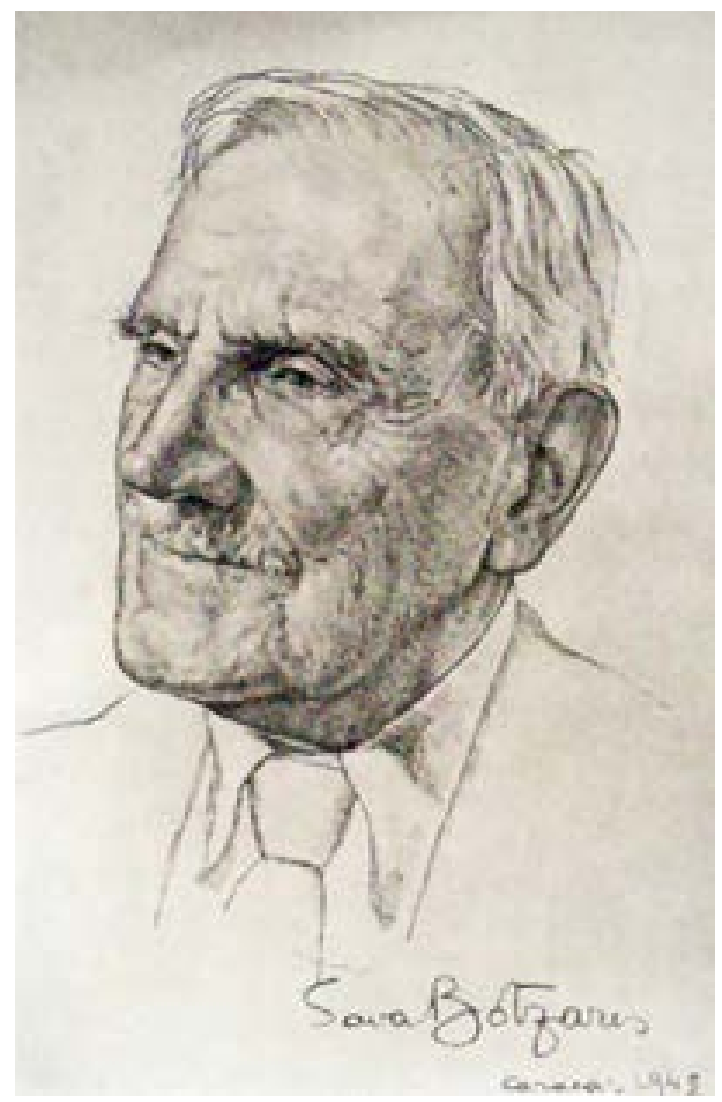

FiguRe 3. Henri Francois Pittier (1857-1950). Portrait by Sava Botzaris (Caracas, 1942).

summoned by Pittier to take over the experimental station, which the United Fruit Company planned to establish in Zent, near the Caribbean port of Limón. This project, however, never came to fruition. Lankester was thus forced to work with different companies until 1908, when he left for England to marry Dorothea Mary Hawker.

First botanical activities (1910-1922). In 1910, he returned to Costa Rica with his wife (Fig. 4), taking over the administration of a coffee farm in Cachí, on the eastern limits of Costa Rica's Central Valley, where he lived for the next nine year. As Amelia and Philip Calvert would write a few years later: "Mr. Lankester's house was beautifully situated half a mile from the Reventazón River and about a hundred and fifty feet above it. It was not a typical Costa Rica residence, for although built of adobe it was two-storied and had no patio. A wide veranda or "corridor" ran across the 


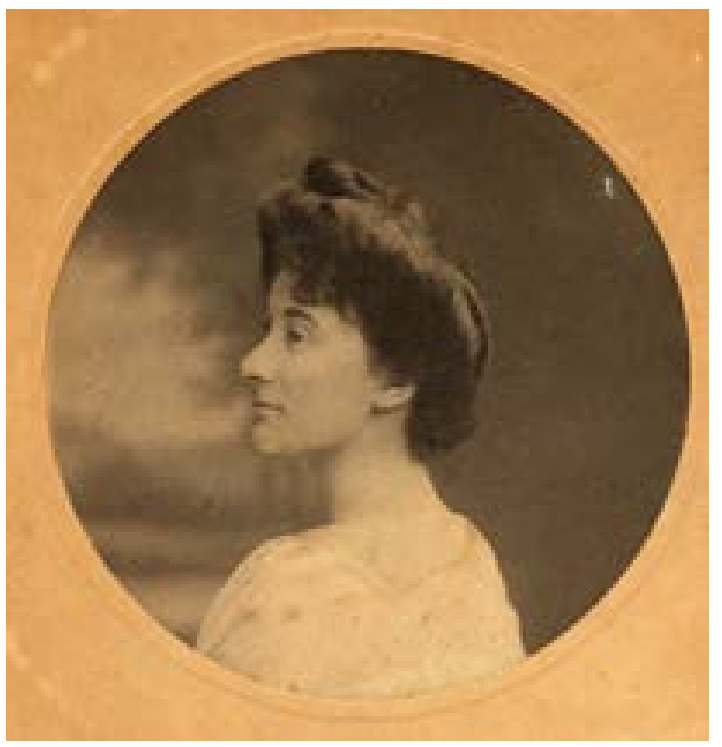

FIGURE 4. Dorothea Mary Hawker, Lankester's wife.

entire front on the first and second floors, charming places, for they were set with plants and hung with baskets of orchids, some of which were in full flower when we were there (Calvert \& Calvert, 1917: 160)" (Figs. 5-6).

Surely influenced by his uncle's zoological background, Lankester was at first interested in birds and butterflies. However, living in Cachí, at that time one of the regions with the greatest botanical diversity, he must have fallen under the spell of the plant world as he soon began collecting orchids in the nearby woods. Many of the plants he collected at this time proved to be new species. With no literature at his hand to determine the plants he collected, Lankester started corresponding with the assistant director of the Royal Botanic Gardens at Kew, Arthur Hill in 1910, and somewhat later with Robert Allen Rolfe, Kew's most eminent authority on orchids.

The first mention of orchids in his correspondence is in a letter to Hill of December 1910, where he wrote: "I have a few orchids chiefly of botanical interest, which I will send when it gets warmer on your side”. Stelis barbata Rolfe (Fig. 7), a plant collected near Cachí and sent to Kew, where it flowered in November 1912 and described by Rolfe in the Bulletin of Miscellaneous Information of Kew in 1913, was the first new orchid discovered by Lankester in Costa Rica. Others would follow: Dichaea ciliolata Rolfe,

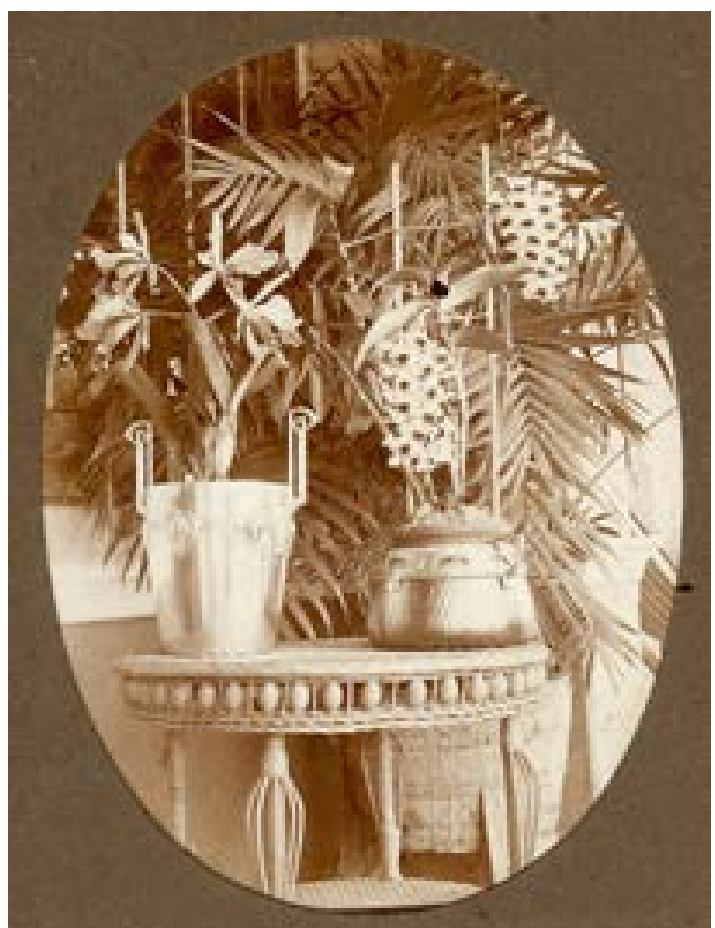

FIGURE 5. Orchids in Lankester's house in Cachí, photographed by himself.

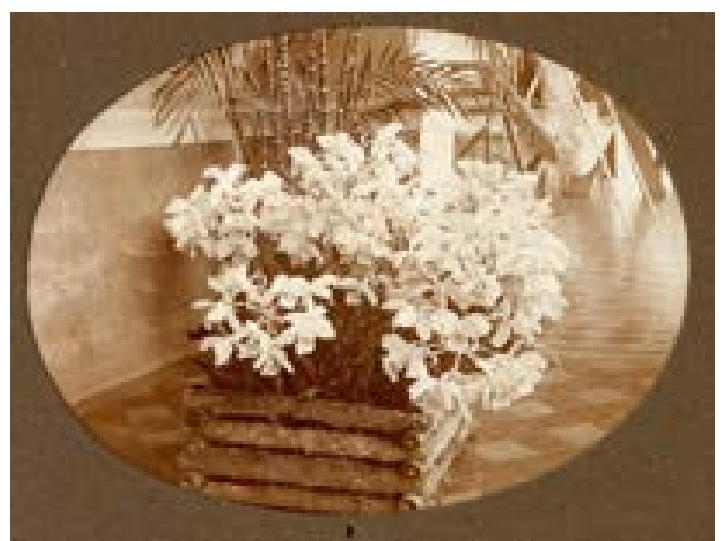

FiguRE 6. Orchids in Lankester's house in Cachí, photographed by himself.

\section{Pleurothallis dentipetala Rolfe and Pleurothallis costaricensis Rolfe.}

At the same time, Lankester began his collection of living plants that would become so famous years later. Lankester returned to England in 1920 to enroll his five children (four daughters and one son) in English schools. Another daughter, his youngest, was born in England that same year. Lankester traveled to Africa 


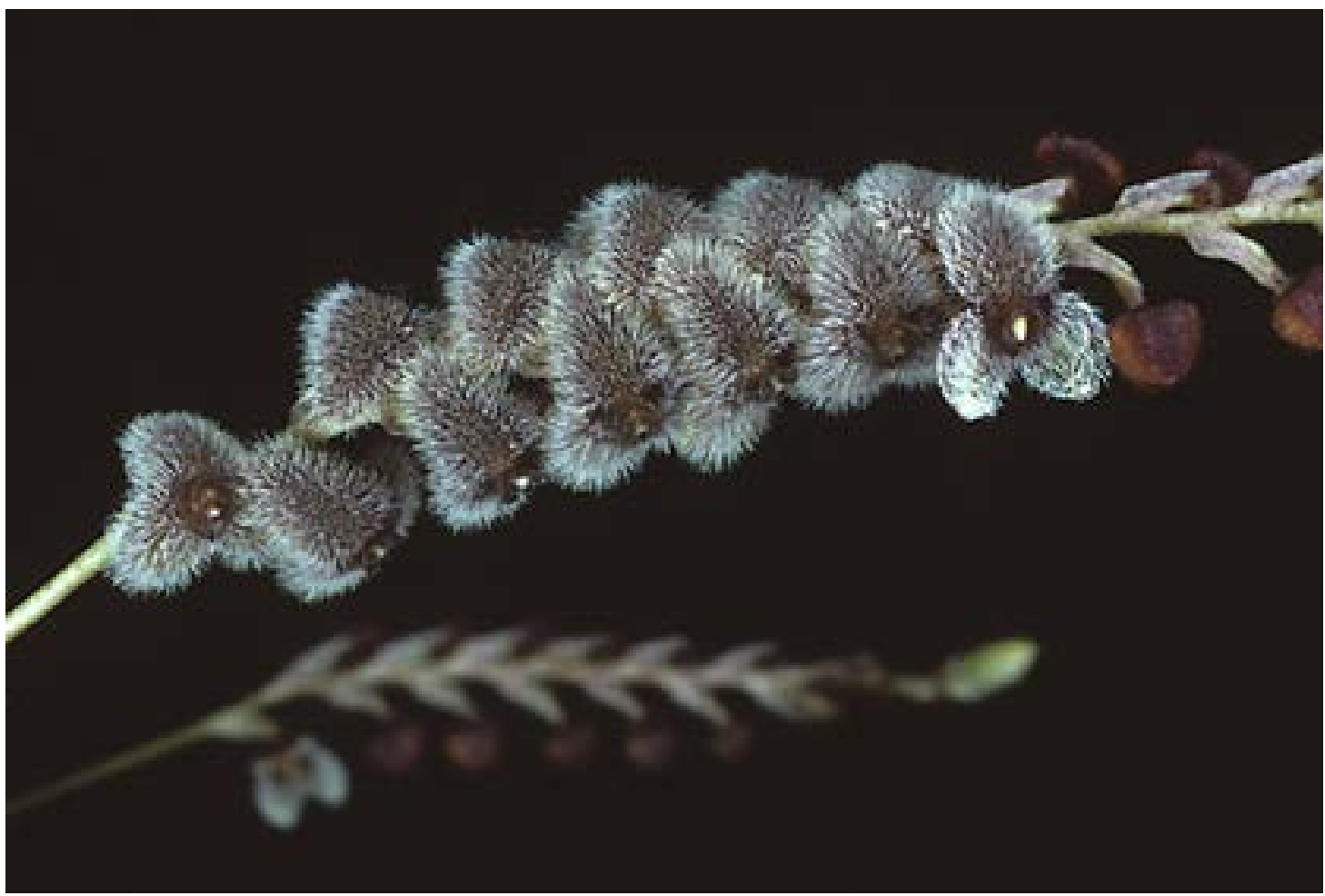

FIgURE 7. Stelis barbata Rolfe, Lankester's first collection of a new orchid species. Photograph by R. Parsons.

from 1920 to 1922, hired by the British Government to do research on coffee plantations in Uganda. When Lankester returned to England, he found that Rolfe had died the year before, just as he was preparing to travel to Costa Rica and Panama on his first field trip to tropical America. Many orchids that Lankester had brought to Kew were left without identification.

The relation with Oakes Ames. Lankester was back in Costa Rica in 1922, the year that was a turning point in his career as an orchidologist: it brought the first correspondence with Oakes Ames (1874-1950) -- the start of a deep and long-lasting friendship.

To understand what was happening in the world of orchidology, it must be remembered that up to the 1920s, the study and knowledge of orchids was strictly an European business. Orchidology in the nineteenth century had been dominated by an Englishman, the great John Lindley (1790-1865), followed by a German, Heinrich Reichenbach junior (or filius, as he liked to be called) (1824-1889). After Reichenbach's death in 1889, Robert Allen Rolfe (1855-1921) became the world's foremost orchidologist, soon challenged and replaced by the German Rudolf Schlechter (1872-1925). It was not until Rolfe's death in 1921, followed by Schlechter's in 1925, that the first American expert on orchids would arise in the figure of Oakes Ames (1874-1950) (Fig. 8), who took a dominant position in the orchid world that was never challenged until his death.

After returning from a trip to Europe, Ames wrote his first letter to Lankester (Sept. 17 1922): “At Kew I saw many specimens collected by you in Costa Rica, the greater part unnamed. As it will take some time for Kew to recover from the loss of Rolfe and as the Germans are making great efforts to assemble Costa Rican material through Wercklé, Jimenez and Tonduz, it seemed to me that you might be willing to co-operate with me by stimulating orchidological interest among your neighbors." And continued: "It would surely be worthwhile if you can see your way clear to send me herbarium specimens and to send collectors into the orchid regions of Costa Rica. I have already identified and described as new, one of your species of Pleurothallis. I refer to P. palliolata (Lankester 192). 


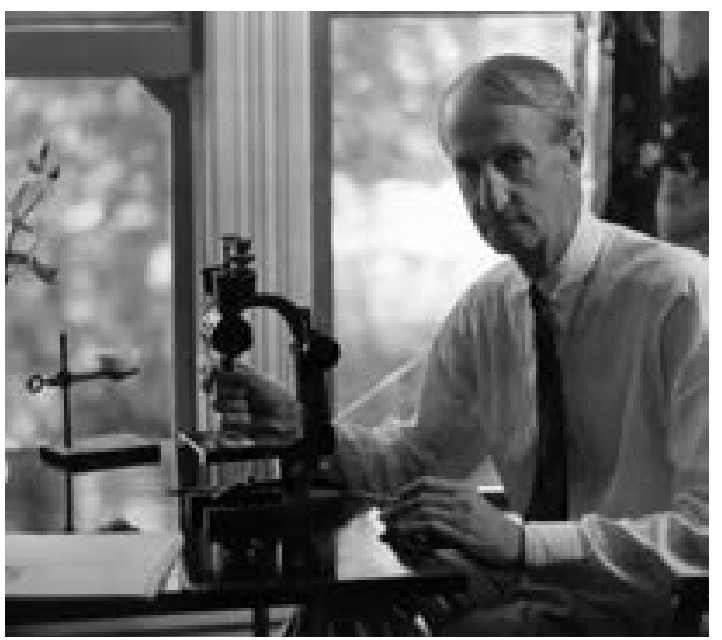

FIgURE 8. Oakes Ames (1874-1950), American orchidologist and founder of the world's largest orchid herbarium.

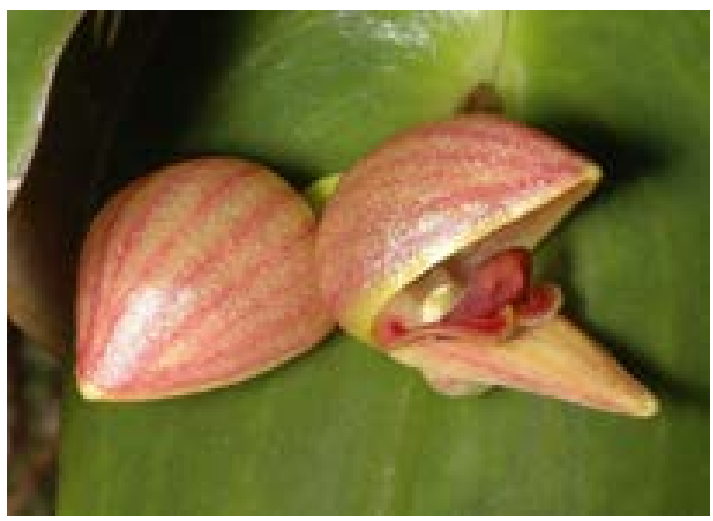

Figure 9. Pleurothallis palliolata Ames, collected by Lankester near his house in Cachí. Photograph by E. Hunt.

The specimen was sent for determination by Hort. Kew" (Fig.9). Ames finished this famous first letter to Lankester by saying: "We must work fast if we hope to keep abreast of the Germans. I was surprised to see how far reaching their efforts have been to secure a monopoly of tropical American species."

We must keep in mind that, at that time, Rudolf Schlechter, the famous German orchidologist, was describing hundreds of new Central American orchid species, based on the collections by Powell in Panama and by Wercklé, Brenes, Tonduz and Jiménez in Costa Rica.

Ames' letter to Lankester was followed by one from Charles W. Powell, who had been collecting for years in Panama and who had met Don Carlos some years earlier. In a letter dated September 25 1922, Powell wrote to Ames: "This will introduce to you (by letter) my good friend Mr. C.H. Lankester, of "Las Cóncavas", Cartago, Costa Rica. Mr. Lankester wishes to take up with you the subject of Costa Rican Orchids, with which he is well familiar. He has a number of specimens now at Kew unidentified or undetermined, which he would like you to have you procure and determine for him. Also he wishes to send to you anything new which he may discover for determination".

In his answer to the letter from Powell, Ames showed his delight in learning that he could count on Lankester's help: "Now that I know from your letter that he has contemplated sending his things to me, this day begins with plenty of sunshine even though heavy clouds obscure the sky (Letter from Ames to Powell, October 6 1922)." Ames was undoubtedly playing a double game: while he could not sever his relations with Schlechter (the German had too much information that Ames needed desperately), he tried to block Schlechter's access to Powell's and Lankester's materials.

Lankester answered Ames' first letter immediately, and went on to become the expert's favorite collector. Over the next fifteen years, Ames would discover more than 100 new species among the specimens he received from Costa Rica. In his letter to Ames of October 11, 1922, Lankester wrote: "I fear stimulation of orchidological interest is exceedingly improbable or likely to be successful in Costa Rica.... I think I alone have the necessary madness. "Orchids had become the center of Lankester's world, and would remain so until his very last day.

In 1922, Ames began a series of publications on orchids, which he named Schedulae Orchidianae. In its third fascicle, in January 1923, Ames started to describe many of the Lankester orchids, which were deposited at Kew and had been left unidentified because of Rolfe's death. Dozens of new species were discovered (see appendix). Ames described more and more new orchids from Costa Rica and kept asking Lankester to send more and more specimens. "Your specimens have arrived... They made my day cheerful to the end. I wished they were more. But if you had sent ten times as many, I would still say that (August, 1923)."

One of the specimens that Lankester sent to Ames was the reason for a famous anecdote: "Your number 


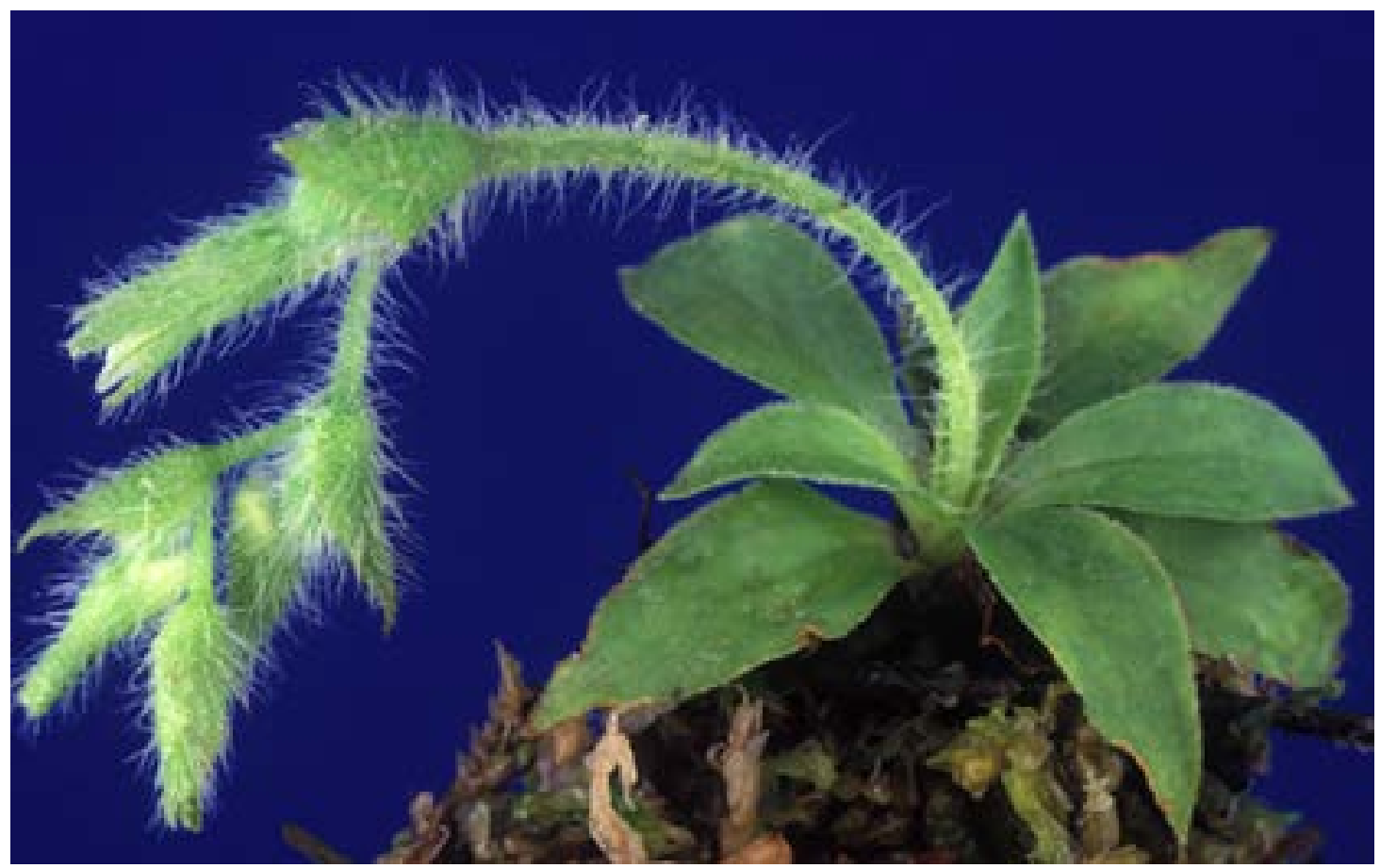

FIgURE 10. Lankesterella costaricensis Ames, the type species of the genus that Ames dedicated to his favorite collector. Photograph by F. Pupulin.

387 is not an orchid, it is a Bromeliad" wrote Ames in 1923. Lankester replied: "Look again". An unusual new orchid genus had been discovered. Ames admitted his error and a week later wrote to Lankester: "There seems to be a new genus among your specimens, Lankesterella would be a good name” (Fig. 10).

After World War I, prices for tropical commodities such as coffee and bananas rose quickly. The restrictions imposed on the import of such goods into Europe and the United States by four years of naval warfare were now replaced by an increasing demand. Owners of coffee plantations in Costa Rica had one of their most prosperous periods during the 1920s, and coffee production and exports increased constantly. Lankester was not the only one to take advantage of the situation. In 1924, he moved to "Las Cóncavas", a coffee farm that he had acquired in the vicinity of Cartago. Coffee had been the reason for his initial emigration from England to Costa Rica, and his livelihood would depend on coffee for the rest of his life.

His orchid collection was already enormous. In August 1924, he wrote to Ames: “...we hope to move over to the 'finca' about the middle of November, this means among other things the translation of about 1,800 orchids over unimaginable roads." It is therefore easy to understand why Lankester's farm would become, over the years, a Mecca for botanists and orchidologists from all over the world. With its beautiful collections of plants, "Las Cóncavas" could not go unnoticed by the world's naturalists. The gardens had important collections of cacti, palms and bromeliads although orchids were always Lankester's favorites. Among the visitors to "Las Cóncavas " were famous names such as Arthur Hill, director of Kew Gardens, Thomas Barbour of Harvard, Harvey Stork, William Maxon, Wilson Popenoe, Philip Calvert, James Rehn and Louis Otho Williams.

By December 1924, after only two years of corresponding with Lankester, Ames had already described 66 new species among his collections. A self-made man with no formal botanical training, Lankester had developed a sharp eye for novelties. The year of 1925 shows us Charles Lankester, who had just reached the age of 45 , at what appears to be the peak of his success as a planter and as an orchidologist. He saw his children again during a 


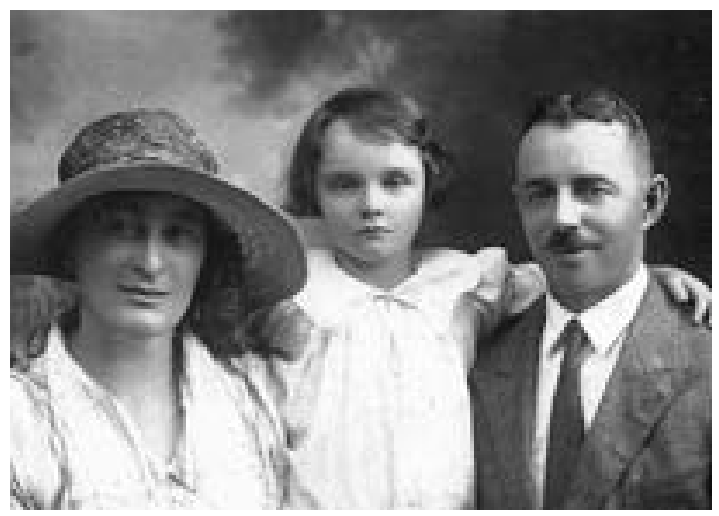

FIGURE 11. Lankester, wife and daughter, 1925.

short trip to England (Fig. 11), his new coffee farm was in full production, and in July of that year he was elected an honorary member of the American Orchid Society (Fig. 12).

What was, however, the real condition of Lankester's business? There seem to have been problems which went largely untold. By 1924, he had already tried to convince Ames to invest in his coffee farm -- a proposal that Ames had politely declined. Then, in November 1925, he seemed to have decided to sell everything and to leave Costa

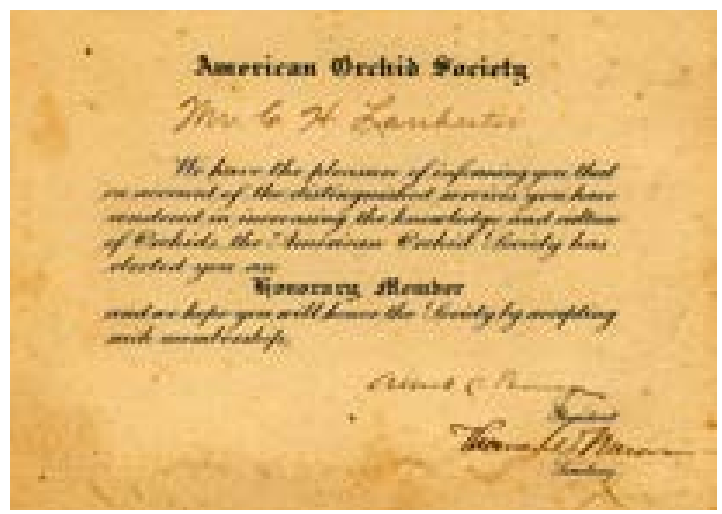

FIGURE 12. Lankester named honorary member of the American Orchid Society.

Rica: "It is just possible I may complete sale of this place during the coming week, if so Costa Rica will soon see me no more." We will probably never know what really happened, but luckily Lankester did not sell and did not leave although it seems that he was never without financial problems until the end of his life. He continued collecting orchids to send to Ames, now often attaching to his herbarium specimens crude sketches or black and white photographs, all preserved today in Ames' documents at the Oakes Ames Orchid Herbarium (Fig. 13).

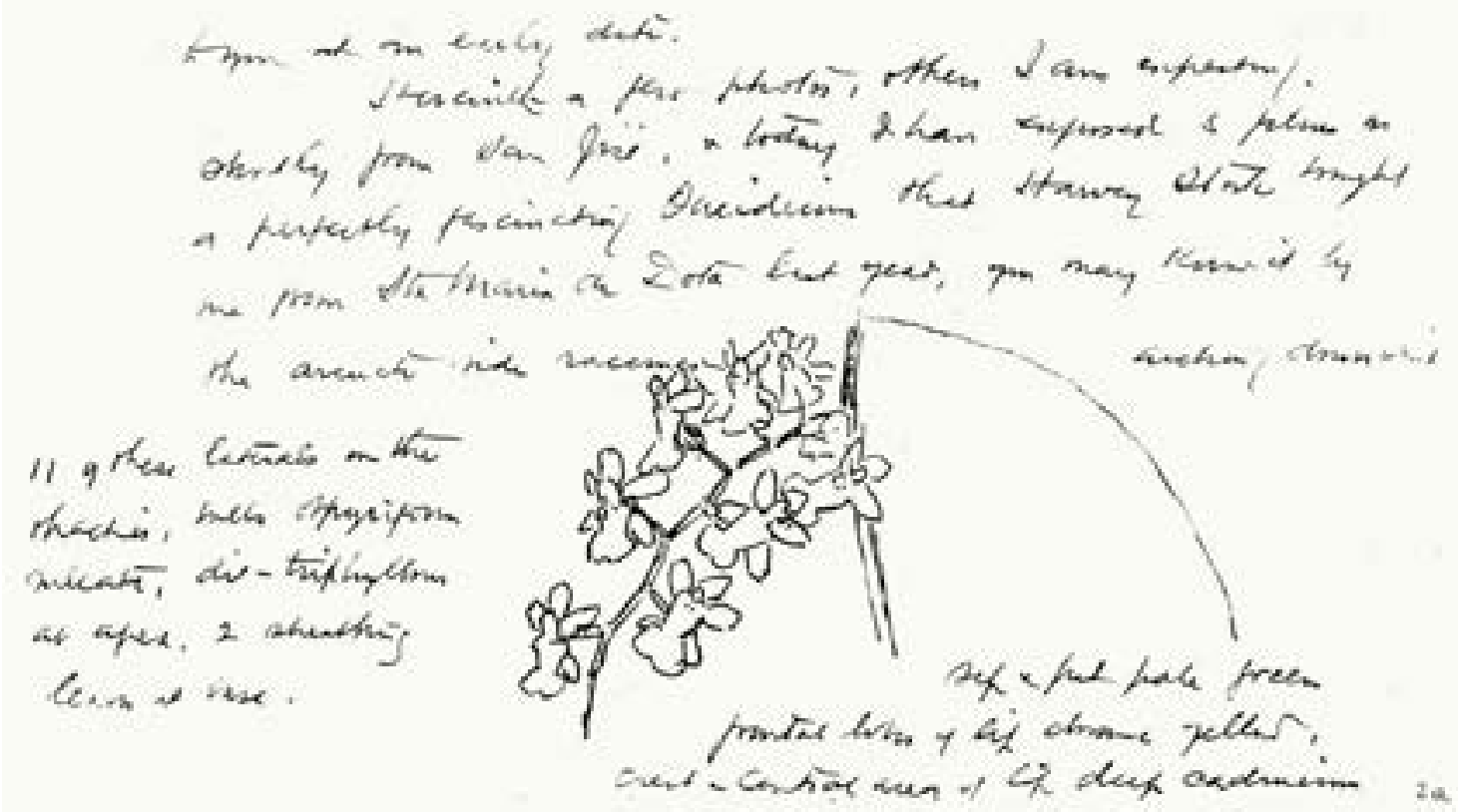

FIGURE 13. Letter from Lankester to Ames, with a sketch of a species of Oncidium. 


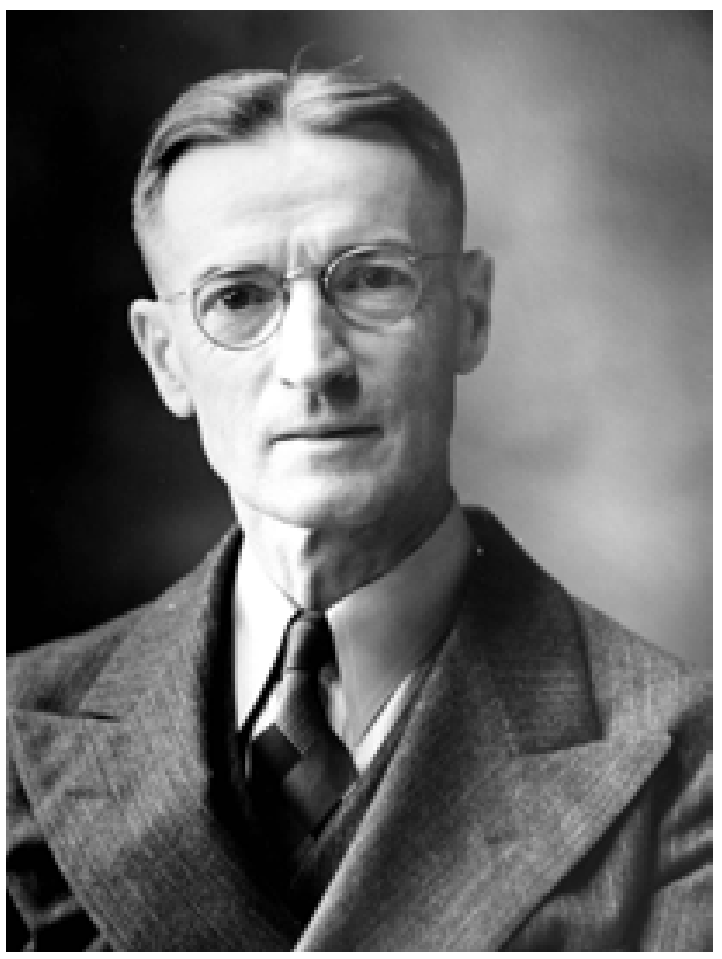

FIGURE 14. Paul Carpenter Standley (1884-1963). Courtesy of Jorge Gómez Laurito.

Paul Standley in Central America (1921-1925). A very special visitor came to Costa Rica in January 1924 and again in December 1925: Paul Carpenter Standley (1884-1963) (Fig. 14). Three years earlier, on December 19, 1921, Standley, a botanist with the U. S. National Museum, had arrived at the port city of $\mathrm{La}$ Libertad, El Salvador , the first visit to Central America of the man who was probably the most important figure in the history of botanical exploration of the region during the first half of the 20th century.

In a conversation with Otón Jiménez, Pittier said: "Much can be expected from such a young and capable element" (Jiménez, 1963: 2). For over 40 years, Standley collected intensively in all of the countries of Central America and published a series of fundamental works about their floras. He acquired an intimate knowledge of the region, not only about its botanical aspects, but also its culture and traditions. He was a friend to all the Central American scientists of his time and contributed like no other to furthering the study and research of the local naturalists and collectors, as well as to the development of existing herbaria and the creation of many new ones. “... Standley hoped that every Central American country would have a botanical library adequate for the study of its flora, and a comprehensive herbarium, formed by local collectors" (McCook, 1999: 119).

Standley arrived in Panama in November 1923. Over the following five months, he collected 7,500 plant specimens in the Canal Zone. In December 1923, January 1924 and during a week in November 1925 (during his second stay in Panama), he collected 800 additional plants on the island of Barro Colorado, recently established as a protected area. As a result of these visits, he wrote his Flora of Barro Colorado Island and the Flora of the Panama Canal Zone, published in 1927 and 1928 respectively, by the Smithsonian Institution.

The two visits by Standley to Panama were followed by extensive collecting trips to Costa Rica, a country that Standley visited during the first months of 1924 and then again between December 1925 and March 1926. Standley collected an enormous amount of material in Costa Rica -- over 15,000 plant specimens, of which no less than 30 orchid species were new to science. "Standley is in New York to-day. When he arrives in Costa Rica, shower orchids on him. Make it a rule that no orchid goes unpressed" (Ames to Lankester, November 13, 1923). "At this stage of the undertaking, quantity rather than quality is important" (id., December 3, 1923). While Standley was working in Honduras, Lankester visited him, and the two became intimately acquainted; they continued to have frequent contact until their later years. Standley always remembered the gesture of the Lankesters in December 1925, while he was collecting in the region of Santa María de Dota: "The writer has not forgotten that they sent a special messenger upon a two days' journey to bring a greeting at Christmas time (Standley, 1937: 59)."

\section{Years of indecision: between England and Costa} Rica (1925-1939). Lankester was still far from finishing with his orchid collections. Ames continued the publication of his Schedulae Orchidianae, now with Charles C. Schweinfurth as co-author. With the publication of fascicle 9 in July 1925, the number of new species collected by Lankester and described by Ames reached 99. In 1927, Lankester visited Charles W. Powell, Panama's famous orchid collector, and 
wrote to Ames in one of his most famous passages: "I have just spent a fortnight with my fellow sufferer from Orchiditis, CWP, and it was a very delightful time of talk and talk and then talk. I wish we could have had you there as High Priest of our cult. Possibly a few tangles might have been unraveled."

After 1930, Lankester and Ames seem to drift slowly apart. Ames was taken in more and more by administrative work at Harvard, and Lankester traveled abroad more frequently. In a letter of April 1932, Ames complained about the separation. "I have missed you. Those little crumbs from your orchidologist feasts always made me feel that you were near at hand. Since your return to England I have felt that you had departed almost to another planet!"

Later in 1932, and back in Costa Rica, Lankester was named by the president of Costa Rica as a member of the board of the National Museum; a great honor that he shared with two other famous figures in the history of the orchids of Costa Rica: Anastasio Alfaro and the grande dame of Costa Rican orchid history, Amparo Zeledón. Abroad again, Lankester visited the Canary Islands in 1934, exploring Tenerife with Professor Balinaga, director of the Botanical Gardens there. The following year he went to Brazil and, after traversing the Continent, left through Bolivia.

In 1934, already 55 years old, Lankester was back in Costa Rica, where he collected the last three orchids that Ames described based on Lankester's collections. These were published between 1934 and 1935 in the Harvard University Botanical Museum leaflets. The orchids were three different species of Stelis: Stelis crystallina, S. latipetala and S. transversalis (Fig. 15).

The American naturalist Alexander F. Skutch (1904-2004), who lived in Costa Rica from 1935 until his death, soon became one of the country's most respected leaders in the study of natural sciences especially ornithology-- and in the development of an original philosophical paradigm for understanding the relationship between mankind and its natural environment. Skutch collected orchids in Guatemala in 1933 and 1934, before moving to Costa Rica, so that it should come as no surprise that he soon met Lankester. In 1950, Skutch married Lankester's daughter Pamela; they spent the rest of their lives on a small farm on the River Peñas Blancas that Skutch named "Los Cusingos", after the local name for the orange beaked-toucanet (Pteroglossus frantzii).

At the end of a decade marked by enormous indecision about his future, torn between his love for his adopted country - despite difficulties - and missing both his homeland and his children, Lankester went to England again before the outbreak of World War II. He returned to Costa Rica with his wife at the end of 1939, very narrowly missing being torpedoed in the convoy in which they crossed the Atlantic; a small ship to the side of them was the unfortunate victim. Lankester's last package of plants was sent to Ames, according to our records, in March 1942 although their correspondence continued until Ames passed away in 1950 .

The final years (1949-1969). In the early 1940's, Lankester began what he meant to be his final tribute to the orchids of his adopted country: a book that would be entitled Costa Rican Orchids. News of this work soon spread, and the orchid world wanted to see it. Paul H. Allen, the foremost expert on the orchids of Panama, wrote to Lankester in 1946: "Through the grapevine, I have heard that you have done a manual on the Orchids of Costa Rica. It is most fortunate in my opinion that you have done so, since you have probably seen more species in the field than any living collector."

Lankester did not only want to write a book, he also wanted to raise funds for the conservation of his farm as a paradise of Costa Rican orchids. He wrote to Rodney Wilcox Jones, president of the American Orchids Society from 1942 to 1948, who gave a polite but clearly negative response: “... I would be inclined to believe there is not much that can be done... Of course, now with your book coming along, I can see where it could be a basis to start an interest in conserving your place as an orchid haven...". The years went by, and the manuscript was never published, although Lankester's dream of preserving his garden was fulfilled a few years after his death.

More and more, Lankester dedicated himself to building up his orchid and plant collections. In 1949, he sold his house in London, deciding to stay in Costa Rica although three of his daughters were married and living in England. As he wrote to Gordon Dillon in 1960: "No idea of returning to live in England, I sold my house in London in 1949, but retain the link of 3 married daughters there, a summer like last years' is certainly inviting, but the winters ..." (Fig. 16). 


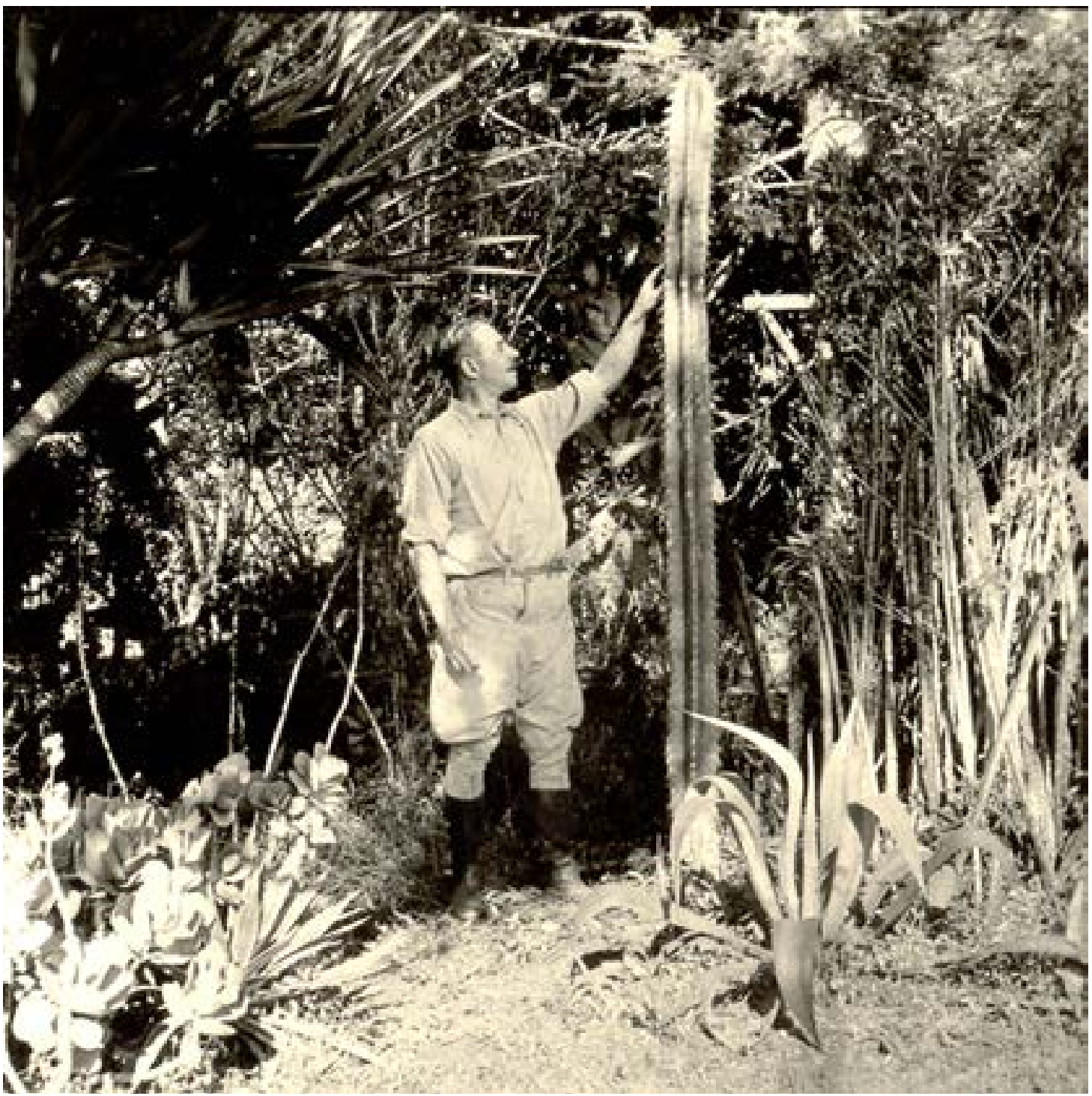

FIGURE 15. Lankester in his garden at "Las Cóncavas", 1936.

In 1955, after his wife's death and already 76 years old, Lankester decided to sell his farm but retained the small part which contained his garden, a piece of land called "El Silvestre". Lankester moved to a house he had bought in Moravia, one of the suburbs of the capital, San José. A few years later, on June 10, 1961, in a ceremony at the British Embassy in San José, Lankester was named an Officer of the Order of the British Empire by order of Queen Elizabeth II, an honor of which Lankester would be proud to the end of his days (Fig. 17). Gordon Dillon had especially gentle words about
Lankester a few months before his death, and in one of his letters called him plantsman extraordinaire.

Charles Herbert Lankester passed away in 1969, alone but for the company of his daughter Dorothy, and having had financial problems during his last years. Shortly before his death, Lankester confessed to Dorothy: "I am only sorry that, with all the opportunities I had, I never made enough money." As one of his friends wrote in his guest book: "Time is unfair to this place and these people" (Fig. 18).

Louis Williams described Lankester in his obituary 


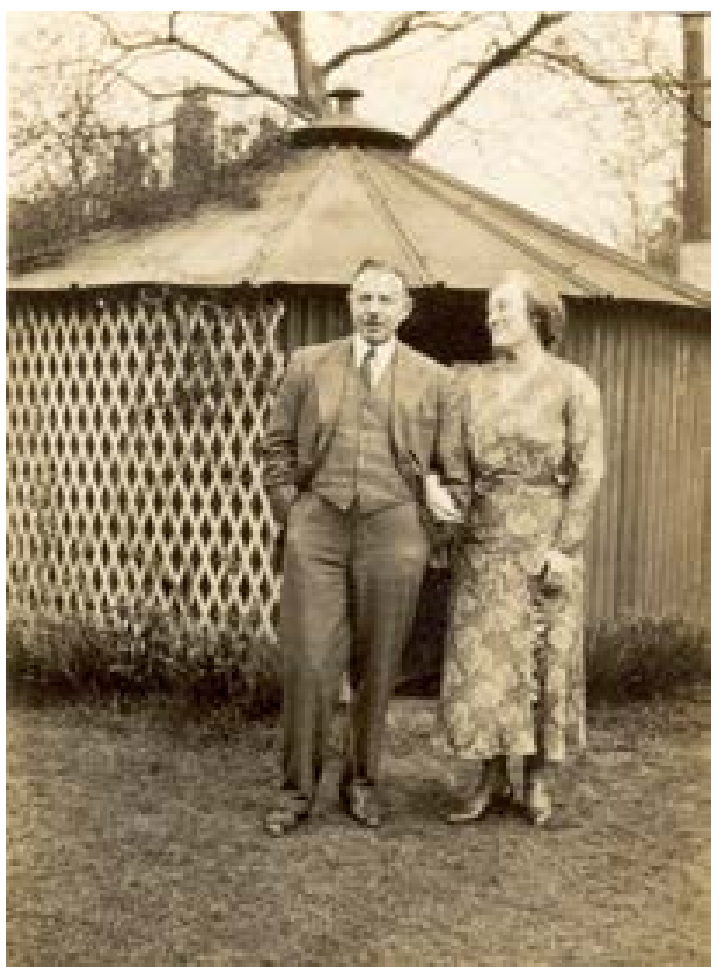

FigURE 16. Lankester with wife Dorothy in 1952.

with these words: "Generous to a fault, hospitable to all, he was counselor to all scientists who came to Costa Rica. His interests were catholic - butterflies, birds, but most especially epiphytic plants, orchids, bromeliads and aroids." And Paul Standley wrote: " $A$ naturalist in the best and widest sense of that word."

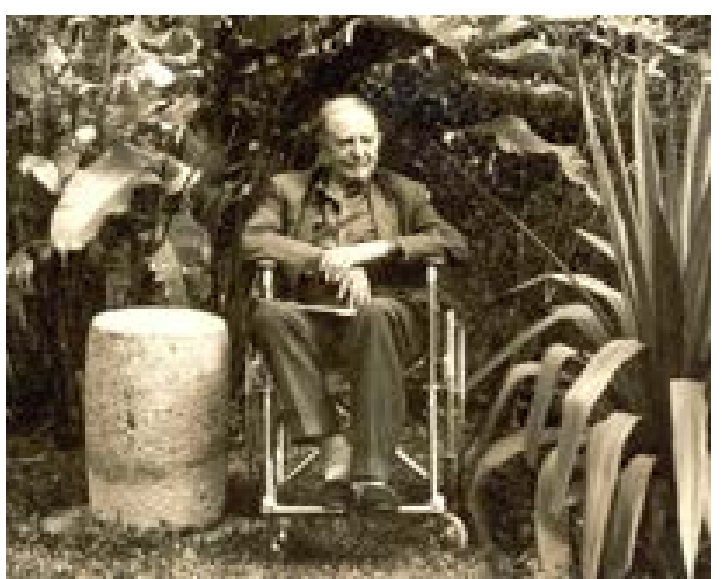

FIGURE 18 . Charles H. Lankester shortly before his death, in his house in Moravia, 1968.

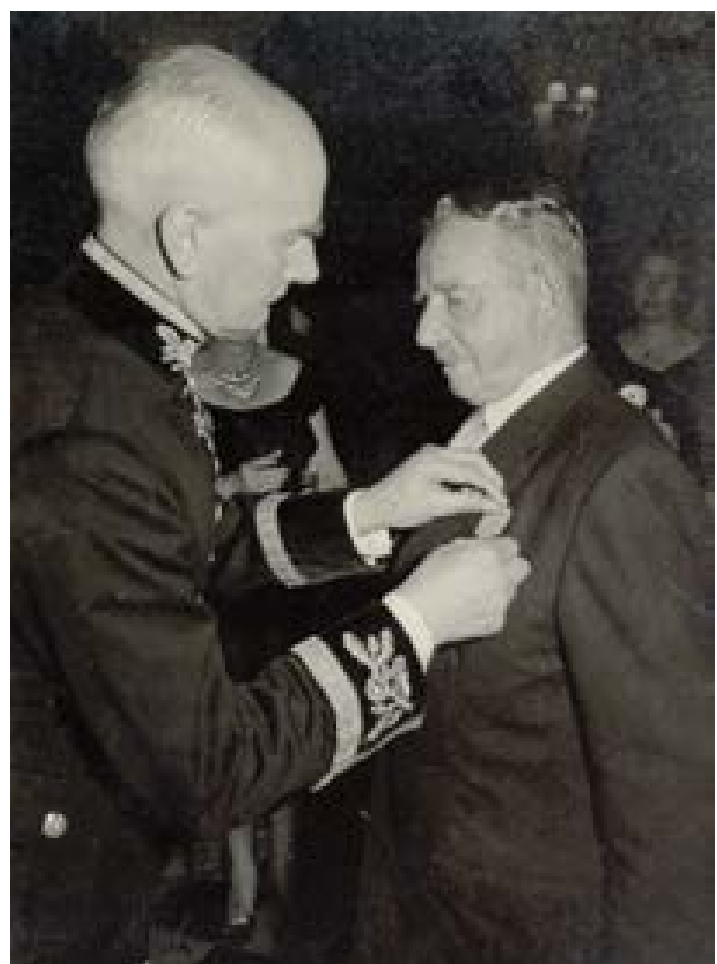

FIGURE 17. Lankester receiving the Order of the British Empire from the British Embassador, San José, 1961.

The Lankester Botanical Garden. "Cóncavas"(= concavities) is the local Spanish name for circular, clayfilled depressions, several hundred feet in diameter and three to four feet-deep. They are frequently found to the east of the Costa Rican city of Cartago. These depressions often fill with water and form large lagoons, a paradise for the migratory birds, which fly to Costa Rica during the last months of the year to escape the harshness of the North American winter.

A coffee farm with the name of "Las Cóncavas" featured one of these beautiful lagoons. Established in the second half of the $19^{\text {th }}$ century by Francisco Quesada, it was bought in 1924 - as we have seen- by Charles $\mathrm{H}$. Lankester (Fig. 19). On a section of this farm called "El Silvestre", Lankester began his wonderful collections of orchids and plants of other families, which formed the basis of the Charles H. Lankester Botanical Garden of the University of Costa Rica.

"El Silvestre", which Lankester kept when he sold the rest of his farm in 1955, was inherited by his daughter Dorothy (Fig. 20), but difficult financial circumstances made it seem impossible to fulfill Lankester's dream of 


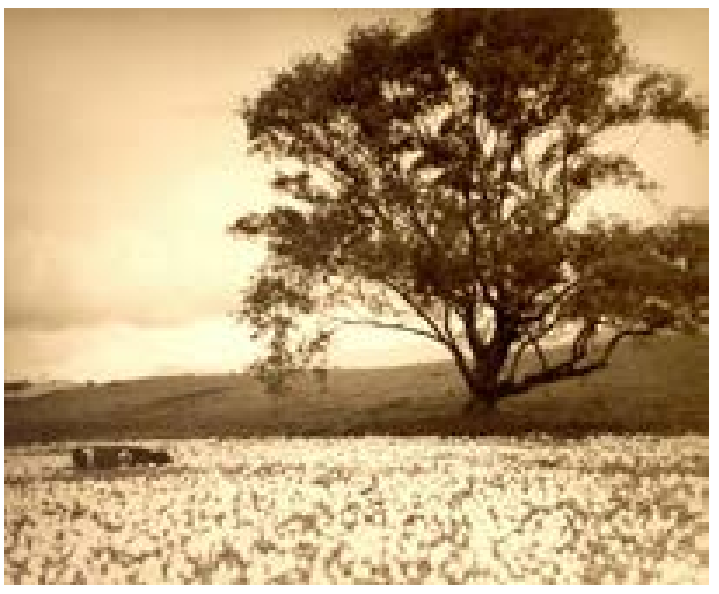

Figure 19. A “concava" at Lankester's farm in Cartago.

Photographed by C. Lankester.

conserving the place as an "orchid heaven". Dorothy was forced to put the garden up for sale. However, through the efforts of the Costa Rican Orchid Society and Costa Rican biologist Rafael Lucas Rodríguez, a group of members of the American Orchid Society (led by Rebecca T. Northen), raised half of the purchase price: $\$ 25,000$. The other half was donated by the Stanley Smith Horticultural Trust of Great Britain. An evaluation committee was formed, and the garden was inspected by Thomas A. Bartenfeld, president of the Conservation Committee of the AOS, Eric Young, president of the Orchid Society of Great Britain and Dr. Calaway H. Dodson, whose expertise on Costa

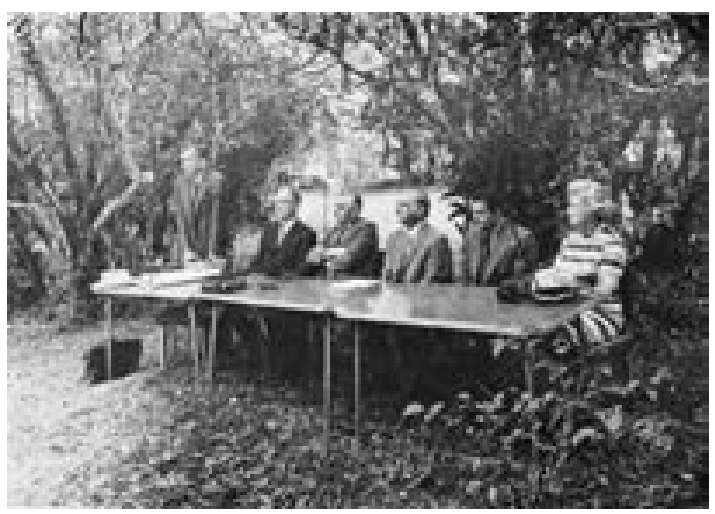

FiguRE 21. Rafael Lucas Rodríguez during the opening address at the inauguration of the Lankester Botanical Garden. Next to him Gordon Dillon, Secretary of the American Orchid Society and to the right Rebecca Northen, who led the fundraising efforts in the United States to buy the gardens.

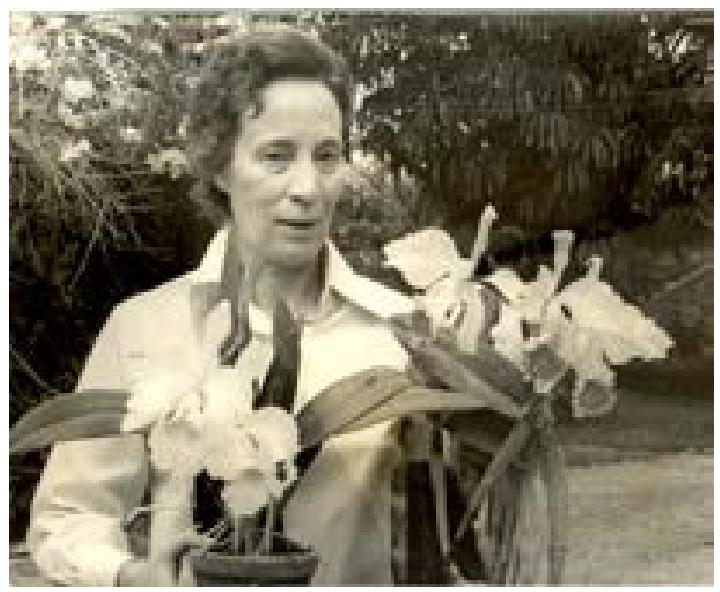

FIGURE 20 . Dorothy Lankester.

Rica was of great value. Their decision was positive, and the funds were deposited. The University of Costa Rica purchased the property and began to operate it as a botanical garden. And so, on March 2 1973, the Charles H. Lankester Botanical Garden was formally inaugurated (Fig. 21).

The first years were difficult. Without a proper budget, the garden could not be kept open to the public and could only be visited by special appointment with Rafael Lucas Rodríguez. It was not until 1979 that the University named Dora Emilia Mora de Retana (Fig. 22) as the first director of the Garden. Under her direction, the garden was slowly transformed from a small farm of 10,7 hectares (aprox. 25 acres) into a world-renowned botanical garden. In a very similar way to Charles Lankester, Dora Emilia turned the Garden into a meeting place for the world's most prestigious orchidologists. Calaway H. Dodson, Norris H. Williams, Robert L. Dressler, John T. Atwood, Carlyle A. Luer, Rudolf Jenny, Eric Hágsater, Henry Oakeley, Günter Gerlach, Klaus C. Horich and many others were frequent guests at Charles Lankester's old farm at "Las Cóncavas". Her interaction with other botanists resulted in 300 Costa Rican orchids being illustrated in the series Icones Plantarum Tropicarum, mostly based on the living collections kept at the gardens. As Atwood remembers, Dora Emilia's did not see Lankester Gardens as just a tourist garden for generating income, but as a garden dedicated to Costa Rican orchid research. In 1984, she organized the first formal course in orchidology in collaboration with Robert L. Dressler, who at the time was a visiting 


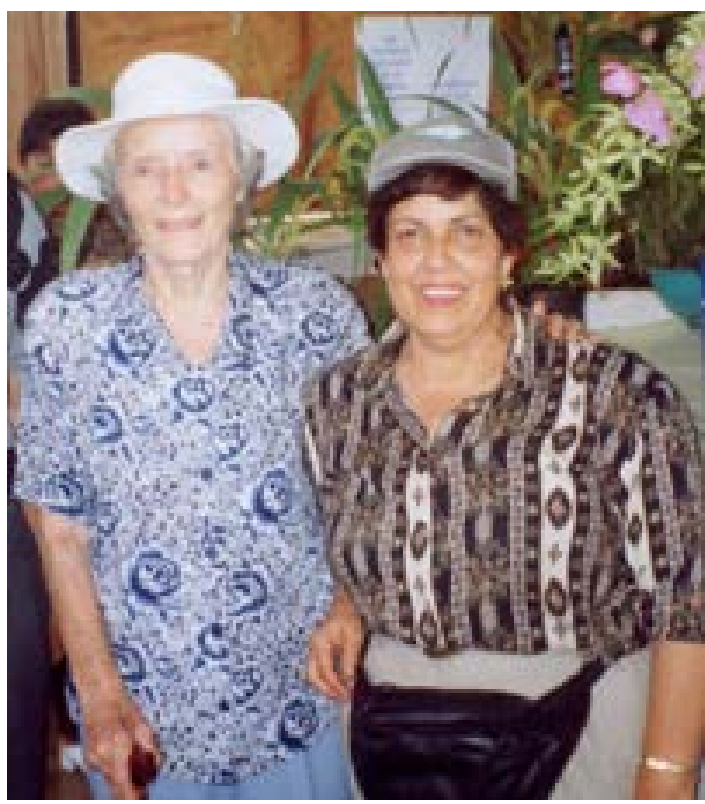

Figure 22. Dora Emilia Mora (right) with Pamela Lankester (left), wife of Alexander Skutch.

professor at the University of Costa Rica. Her main scientific legacy to the knowledge of Costa Rican orchid taxonomy was the treatment of the subtribes Maxillarinae and Oncidiniinae for the Flora Costaricensis, prepared in collaboration with John Atwood.

Many new orchid species were dedicated to Dora Emilia Mora de Retana. Hágsater named his Epidendrum mora-retanae in her honor, Gerlach his Kefersteinia retanae, Dressler his Sobralia doremiliae, Luer his Stelis morae and Dodson \& Escobar their Telipogon retanae.

We leave Dora Emilia with Atwoods' final words in her obituary: “...her greatest legacy is to rise above personal ambitions to foster efforts of those around her. Because of her, Lankester Gardens is blessed with a talented, imaginative, and altruistic staff..."

Joaquín B. García Castro (1944-2001) (Fig. 23), called "Quincho" by his friends, was Dora Emilia's friend and main collaborator for over 25 years. Together, they published the first checklist of Costa Rican orchids after Paul Standley's Flora of Costa Rica (1937), to which Oakes Ames had contributed with the treatment of Orchidaceae. In this Lista actualizada de las orquideas de Costa Rica, Dora Emilia and Joaquín García added 46 genera and 467 species to the previous catalogue.

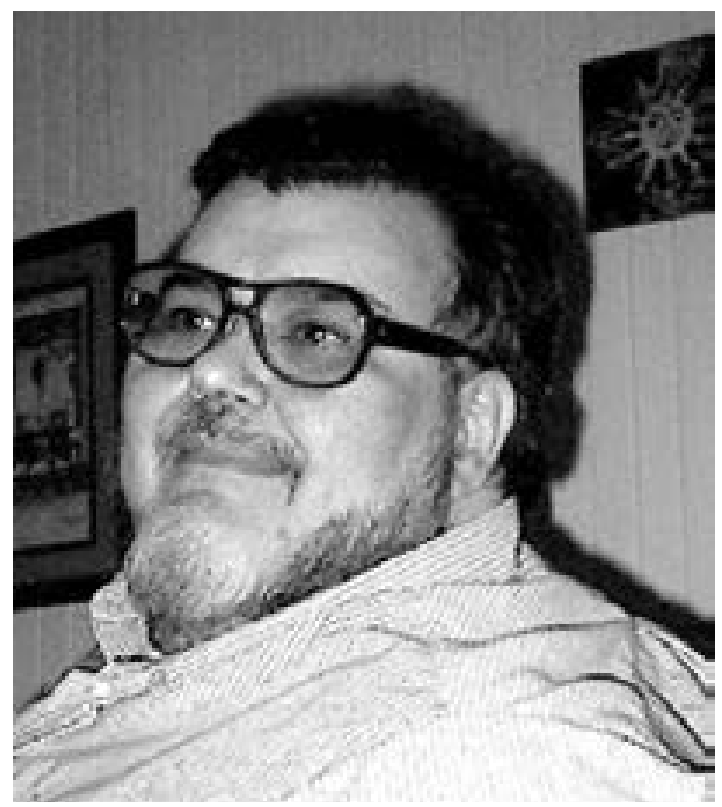

Figure 23. Joaquín Bernardo García Castro (1944-2001). Photograph by Eduardo Bitter.

A doctor of medicine and a university professor, Joaquín García was, for many years, the mentor of numerous Costa Rican orchid lovers. A brilliant scholar, Joaquín liked to lecture his friends on complicated themes, such as the biochemistry of colors in orchid flowers or the fundamentals in orchid hybrid genetics. As John Atwood liked to say: "I don't have the brains of Joaquín, therefore I need a well-organized library." Always generous with his knowledge and his time, Joaquín served several terms as president of the Costa Rican Orchid Society. Shortly after his death, Franco Pupulin named Prosthechea joaquingarciana in his honor.

The Lankester Botanical Garden has become the most important center for orchid research in Central America and the Caribbean. For this reason, in 2003 the University of Costa Rica changed its status and converted the garden into an 'experiment station'. In December 2005, the Ministry of the Environment declared the Lankester Botanical Garden "National Center for the Conservation of Flora" and "National Epiphyte Sanctuary". For its institutional merits, Luer named Masdevallia lankesteriana, and Pupulin named Chondrorhyncha lankesteriana (today Stenotyla lankesteriana) in honor of the gardens. 


\section{LITERATURE CITED}

Atwood, J.T. 2001. Dora Emilia Mora de Retana, a remembrance. Lankesteriana 2: 9.

Jiménez, O. 1963. Paul C. Standley. Chicago Natural History Museum Press.

Jiménez, O. 1963. 1967. Charles Herbert Lankester. Revista de Agricultura, Oct. 1967: 248-264.

McCook, S. 1999. Creole Science: Botanical Surveys of Costa Rica, 1880-1940. Endeavour 23(3): 118-120.

Northen, R. 1964. Charles H. Lankester - Orchidologist of Costa Rica. Amer. Orchid Soc. Bull. January 1964: 4350.

Ossenbach, C. 2003. Breve Historia de la Orquideología en Costa Rica. Editorial de la Universidad de Costa Rica.

Ossenbach, C. 2006. Orchids in Costa Rica - Part II: Charles
H. Lankester and Oakes Ames. Orchids (West Palm Beach), February 2006: 120-127.

Ossenbach, C. 2006. Orchids in Costa Rica - Part IV: The Charles H. Lankester Botanical Garden. Orchids (West Palm Beach), April 2006: 284-291.

Ossenbach, C. 2009. Orchids and Orchidology in Central America: 500 years of history. Lankesteriana 9 (1-2): 1-268.

Schlechter, R. 1923. Additamenta ad Orchideologiam Costaricensem. Repert. Sp. Nov. Regni Veg. 19.

Standley, P.C. 1937. Flora of Costa Rica, Part I. Field Museum of Natural History, Botanical Series, Vol. 18, publication 391 .

Williams, L.O. 1969. In Memoriam: Charles Herbert Lankester - 1879-1969. Amer. Orchid Soc. Bull. : 860862.

APPENDIX

New orchid species collected by Charles Lankester

Campylocentrum lankesteri Ames

Campylocentrum longicalcaratum Ames \& C.Schweinf.

Chondrorhyncha estrellensis Ames

Cranichis lankesteri Ames

Cranichis saccata Ames

Cryptocentrum gracillimum Ames \& C.Schweinf.

Dichaea ciliolata Rolfe

Dichaea lankesteri Ames

Dichaea verrucosa Ames \& C.Schweinf.

Elleanthus tricallosus Ames \& C.Schweinf.

Epidendrum adnatum Ames \& C.Schweinf.

Epidendrum bilobatum Ames

Epidendrum circinatum Ames

Epidendrum crescentilobium Ames

Epidendrum cristobalense Ames

Epidendrum dentiferum Ames \& C.Schweinf.

Epidendrum dolabrilobum Ames \& C.Schweinf.

Epidendrum equitantifolium Ames

Epidendrum estrellense Ames

Epidendrum exile Ames

Epidendrum intermixtum Ames \& C.Schweinf.

Epidendrum lankesteri Ames

Epidendrum nervosiflorum Ames \& C.Schweinf.

Epidendrum peraltense Ames

Epidendrum ramosissimum Ames \& C.Schweinf.

Epidendrum rugosum Ames

Epidendrum santaclarense Ames

Epidendrum vagans Ames

Habenaria lankesteri Ames

Hexisea lankesteri Ames

Hexisea sigmoidea Ames \& C.Schweinf.
Lankesterella Ames

Lankesterella costaricensis Ames

Lepanthes cascajalensis Ames

Lepanthes chameleon Ames

Lepanthes estrellensis Ames

Lepanthes exasperata Ames \& C.Schweinf.

Lepanthes eximia Ames

Lepanthes grandiflora Ames \& C.Schweinf.

Lepanthes micrantha Ames

Lepanthes rostrata Ames

Lepanthes sanchoi Ames

Lepanthes subdimidiata Ames \& C.Schweinf.

Lepanthes tridens Ames

Limodorum lankesteri Ames \& C.Schweinf.

Lockhartia lankesteri Ames

Malaxis lankesteri Ames

Malaxis uncinata Ames \& C.Schweinf.

Masdevallia fimbriata Ames \& C.Schweinf.

Maxillaria arachnitiflora Ames \& C.Schweinf.

Maxillaria confusa Ames \& C.Schweinf.

Maxillaria foliosa Ames \& C.Schweinf.

Maxillaria lankesteri Ames

Notylia lankesteri Ames

Oncidium lankesteri Ames

Ornithidium lankesteri Ames

Ornithocephalus lankesteri Ames

Physosiphon obliquipetalus Ames \& C.Schweinf.

Pleurothallis angusta Ames \& C.Schweinf.

Pleurothallis arietina Ames

Pleurothallis cachensis Ames

Pleurothallis cerea Ames 
Pleurothallis costaricensis Rolfe

Pleurothallis crassilabia Ames \& C.Schweinf.

Pleurothallis crescentilabia Ames

Pleurothallis cucullata Ames

Pleurothallis dentipetala Rolfe ex Ames

* Pleurothallis dichotoma Ames (nom. ill.)

Pleurothallis geminicaulina Ames

Pleurothallis glomerata Ames

Pleurothallis longipedicellata Ames \& C.Schweinf.

Pleurothallis nana Ames \& C.Schweinf.

Pleurothallis palliolata Ames

Pleurothallis papilliferaRolfe

Pleurothallis peperomioides Ames

Pleurothallis peraltensis Ames

Pleurothallis peregrina Ames

Pleurothallis periodica Ames

Pleurothallis pompalis Ames

Pleurothallis rectipetala Ames \& C.Schweinf.

Pleurothallis saccata Ames

Pleurothallis sanchoi Ames

Pleurothallis scandens Ames

Pleurothallis segregatifolia Ames \& C.Schweinf.

Pleurothallis strumosa Ames

Pleurothallis vinacea Ames

Restrepia lankesteri Ames \& C.Schweinf.
Scaphyglottis bicallosa Dressler

Sobralia atropubescens Ames \& C.Schweinf.

Sobralia carazoi C.H. Lank. \& Ames

Sobralia mucronata Ames \& C.Schweinf.

Spiranthes lankesteri Standl. \& L.O.Williams

Stelis barbata Rolfe

Stelis carnosiflora Ames \& C.Schweinf.

Stelis cascajalensis Ames

Stelis crystallina Ames

Stelis cucullata Ames

Stelis cuspidata Ames

Stelis distantiflora Ames

Stelis elliptica Ames \& C.Schweinf.

Stelis fractiflexa Ames \& C.Schweinf.

Stelis glandulosa Ames

Stelis lankesteri Ames

Stelis latipetala Ames

Stelis minutiflora Ames \& C. Schweinf. (nom. ill.)

Stelis propinqua Ames

Stelis sanchoi Ames

Stelis transversalis Ames

Stelis vestita Ames

Stellilabium distantiflorum Ames \& C.Schweinf.

Stenorrhynchus bracteosus Ames \& C.Schweinf.

New species collected by Lankester in other plant families

\section{ASTERACEAE}

Vernonia lankesteri S.F.Blake ex Standl.

BROMELIACEAE

Araeococcus pectinatus L.B.Smith

CACTACEAE

Discocactus lankesteri Kimnach

CAPPARACEAE

Capparis lankesteri Standl.

EUPHORBIACEAE

Croton triumfettoides Croizat

MALVACEAE

Wercklea lutea Rolfe

\section{PIPERACEAE}

Peperomia lankesteri Trel.

RANUNCULACEAE

Thalictrum lankesteri Standl.

SAPOTACEAE

Bumelia lankesteri Standl.

SOLANACEAE

Lycianthes lankesteri Standl.

VERBENACEAE

Citharexylum lankesteri Moldenke 